\title{
A REPORT OF A PATIENT WITH NIEMANN-PICK DISEASE TYPE B AND A REVIEW OF THE PATIENTS IN JAPAN
}

\author{
Yukuo KonISHI, ${ }^{1, *}$ Kaoru KonISHI, ${ }^{1, * *}$ Teizo Tomisawa, ${ }^{1}$ Toru Momor, ${ }^{2}$ \\ Masakatsu Sudo, ${ }^{2}$ Eiji Yamada, ${ }^{3}$ and Fumitada HazAma ${ }^{3}$ \\ ${ }^{1}$ Department of Pediatrics, Fukui Red Cross Hospital, Fukui 910, Japan \\ ${ }^{2}$ Department of Pediatrics, Faculty of Medicine, Kyto University, \\ Kyoto 606, Japan \\ ${ }^{3}$ Department of Pathology, Shiga University of Medical Science \\ School of Medicine, Ohotsu 520-21, Japan
}

Summary A three year-eight month old Japanese girl with NiemannPick disease type B was reported. She was short in stature. There was a hepatosplenomegaly and an abnormality on the chest X-ray. Bone marrow aspiration smear showed typical Niemann-Pick cells.

Sphingomyelinase activities of the leucocytes and liver were assayed. The enzyme activities of both leucocytes and liver were profoundly low and the parents had leucocyte enzyme activities between the patient's and controls'.

Electronmicroscopy of the biopsied liver and lymphnodes from the patient revealed numerous cytoplasmic inclusion bodies.

Three cases of the chronic type of the disease with sphingomyelinase deficiency reported in Japan were reviewed on clinical features and laboratory findings and the phenotypic variabilities among these patients were discussed.

Our patient was the first typical Niemann-Pick disease type B patient in Japan.

\section{INTRODUCTION}

Niemann-Pick disease is an inborn error of lipid metabolism characterized by hepatosplenomegaly, an infiltration of foamy cells (Niemann-Pick cells) and abnormal accumulation of sphingomyelin in various organs (Niemann 1914, Pick 1927, Pick and Bielschowsky 1927). Crocker (1961) outlined four subroups based on the combined clinical and chemical studies. The type of this disease seen in adult

Received April 3, 1981

* Present address: Department of Pediatrics, Faculty of Medicine, Kyoto University, Kyoto 606, Japan.

** Present address: Department of Pediatrics, Kisshoin Hospital, Kyoto 601, Japan. 
was added as the fifth form by Fredrickson and Sloan (1972). A deficiency in the sphingomyelinase activity is clearly evident in the organs of patients with the disease of type A and B (Sloan et al., 1969). However, enzyme activities in patients with the disease of type $\mathrm{C}, \mathrm{D}$ and $\mathrm{E}$ varied with the reports (Callahan et al., 1974; Schneider and Kennedy 1967) and enzymatic defects in those patients have not been clarified.

In these five groups, reports of type B are less frequent than those of types A and C. In Japan, only three cases of the chronic type of Niemann-Pick disease with a considerable sphingomyelinase deficiency have been found in children (Sogawa et al., 1976; Sogawa et al., 1978; Uetani et al., 1978).

In this communication, we report the first typical case of Niemann-Pick disease type $B$ in Japan and summarized other cases.

\section{CASE REPORT}

The patient, M.I., a three year-eight month old Japanese girl was admitted to the Fukui Red Cross Hospital for evaluation of hepatosplenomegaly. She was the product of a full term pregnancy and uneventful delivery. She weighed $3,280 \mathrm{~g}$ at birth and was considered to be a healthy newborn. At the age of five months, she was treated with antibiotics for a pyothorax. At that time, hepatosplenomegaly was pointed out by a physician. Since then, she had had frequent bouts of respiratory infection. Her parents were healthy Japanese and not consanguineous. Her elder brother is healthy.

On admission, she was small for her age (weight $12 \mathrm{~kg}$ and height $85.5 \mathrm{~cm}$ ) and had a distended abdomen. Neither her skin nor conjunctivae was icteric. There was no lymphadenopathy. She was not mentally retarded and no abnormal neurological findings were observed. The general physical examinations were notable for a sharply defined non-tender, nonnodular liver edge three fingerbreadths below the right costal margin and spleen felt four fingerbreadths below the left costal margin.

Peripheral hemogram showed no abnormalities. Bleeding time was prolonged and bone marrow aspiration showed the cells typical of Niemann-Pick disease. The serum GOT, GPT and alkaline phosphatase were slightly elevated but the other liver function tests were normal. Serum protein, protein electrophoresis, electrolytes, calcium, phosphorus, fasting blood glucose and immunoglobulins were all normal.

Serum triglyceride was $288 \mathrm{mg} / \mathrm{dl}$ (normal $66-172 \mathrm{mg} / \mathrm{dl}$ ): $\beta$-lipoprotein 645 $\mathrm{mg} / \mathrm{ml}$ (normal $150-450 \mathrm{mg} / \mathrm{d} 1$ ). The chest X-ray film showed a fine punctate infiltration of the lungs. The electroencephalogram was normal. The liver RI scanning revealed characteristic change of a diffuse parenchymal liver disease.

Liver and lymphnodes biopsies were performed with the informed consent of the parents. Histopathological and enzymatic studies were done on the biopsied specimens and the leucocytes enzyme assays of the patient and members of her 
immediate family were also done.

She is five year-eight month old and is in apparent good health with no untoward neurological symptoms. However, the size of her liver and spleen has increased to $6 \mathrm{~cm}$ and $8 \mathrm{~cm}$ palpable below the right and left costal margins, respectively.

\section{MATERIALS AND METHODS}

Tissues for electron microscopy were obtained by biopsy from the liver and lymphnodes. The specimens were fixed in glutaraldehyde in phosphate buffer $(\mathrm{pH}$ 7.4) and post fixed in cold osmiun tetroxide buffered to $\mathrm{pH} 7.4$ with veronal acetate. The specimens were embedded in Epon and stained with uranyl acetate and lead citrate. Remaining tissues were fixed in $10 \%$ neutral formalin and stained with hematoxylin-eosin (H.E.), Azan, Sudan black B, Sudan III and P.A.S. methods.

Sphingomyelinase activities in the liver and leucocytes were assayed by the method of Sloan et al. (1969) with slight modifications as follows. Sphingomeylin was purchased from Sigma Chemical Company (U.S.A.) and [methyl-14C]sphingomyelin was synthesized (specific activity, $59.4 \mu \mathrm{Ci} / \mu \mathrm{mol}$ ) according to the method of Stoffel et al. (1971) using [methyl- ${ }^{14} \mathrm{C}$ ]iodide (The Radiochemical Centre, Amersham, England). A liver specimen from the patient was obtained by open biopsy and specimens from six children who died of various causes other than inherited metabolic disorders were obtained at autopsy, as the control specimens. Tissues were stored at $-20^{\circ} \mathrm{C}$ until analysis. Liver specimens were homogenized in 10 volumes of $0.1 \%$ Triton X-100. Leucocytes specimens were obtained from the patient, her brother, her parents and apparently healthy adults. Informed consent was obtained from each person and/or their parents. Leucocyte homogenate was made with $0.1 \%$ Triton $\mathrm{X}-100$ instead of water.

Whole homogenate of the liver and leucocytes was used as the enzyme solution. Protein concentration was determined by the method of Lowry et al. (1951). The assay mixture consisted of $50 \mu 1$ of $0.1 \%$ Triton X-100 and $80 \mu 1$ of homogenate solution (in the case of liver specimens, $20 \mu l$ of homogenate was mixed with $60 \mu 1$ of $0.1 \%$ Triton $\mathrm{X}-100$ ). The following procedures were the same as those described by Sloan et al. (1969).

Four other lysosomal enzymes, such as $\beta$-galactosidase, $\beta$-glucuronidase, $\alpha$ mannosidase and $\beta$-glucosaminidase were also assayed for leucocyte specimens, the method of which was described previously (Sudo et al., 1978).

\section{RESULTS}

\section{Pathological findings}

Light microsopic findings. On H.E. stain, both hepatic and Kupffer cells had a light and ballooned cytoplasm. It was difficult to distinguish between them in 
the H.E. stained preparations. In the periportal area, there were numerous macrophages which had a light and swollen cytoplasm (Fig. 1). With Azan stain, cytoplasm of the liver cells was stained reddish and numerous granules were observed. On the other hand, cytoplasm of the Kupffer cells was stained light blue and fine reticular structure was observed. Thus, the liver cells and Kupffer cells could be readily differentiated. Many foamy cells were observed in the lymphnodes and these cells stained positively with Sudan black B, faintly with Sudan III and negatively with P.A.S. reaction.

Electron microscopic findings. The reticular cells of lymphnodes were filled with cytoplasmic inclusion bodies, some of which took the shape of a concentric lamellar body (Fig. 2) similar to the membranous cytoplasmic body (MCB) in TaySachs disease and other to Zebra body (Fig. 3). The ballooned Kupffer cells were filled with inclusion bodies. As compared to findings in Tay-Sachs MCB, these inclusion bodies were smaller and more irregular in sise and shape. Their lamellar structures were loose and the center was more electron lucent (Fig. 4). The liver cells also had a small number of inclusion bodies.

\section{Enzyme activities}

Sphingomyelinase activities of the patient's liver were extremely low (Table 1). The activity of the enzyme in leucocytes from the patient was low and in the parents the activities were between those seen in the patient and in the control's.

Other lysosomal enzymes such as $\beta$-galactosidase, $\beta$-glucuronidase, $\beta$-glucosaminidase and $\alpha$-mannosidase were all within normal limits (Table 2).

\section{DISCUSSION}

Types A, B, C and D of Niemann-Pick disease appear to be autosomal recessive disease (Fredrickson and Sloan, 1972). In type A, almost half the number of patients are of Ashkenazic Jewish descent. On the other hand, in Types B and C, there is no ethnic predisposition.

Type $\mathrm{B}$ is a chronic form without neurological involvement. These children show remarkable hepatosplenomegaly and lymphadenopathy early in infancy, but may reach adulthood in relatively good health. In this type, pulmonary alteration is often seen on roentgenologic examination. The patients frequently develop recurrent pulmonary infection. Regarding clinical features and findings in the enzyme studies, our patient was a typical case of Niemann-Pick disease Type B. Pathologically, foamy cells of the bone marrow and lymphnodes were typical of this disease. Cytoplasmic inclusion bodies were seen electronmicroscopically in the liver and lymphnodes, however, the size and shape were more irregular and smaller as compared with those of Tay-Sachs disease.

In Japan, only three cases of Niemann-Pick disease showing chronic course of illness and profound sphingomyelinase deficiency have been reported (Sogawa et al., 1976; Sogawa et al., 1978; Uetani et al., 1978). Table 3 summarizes the 


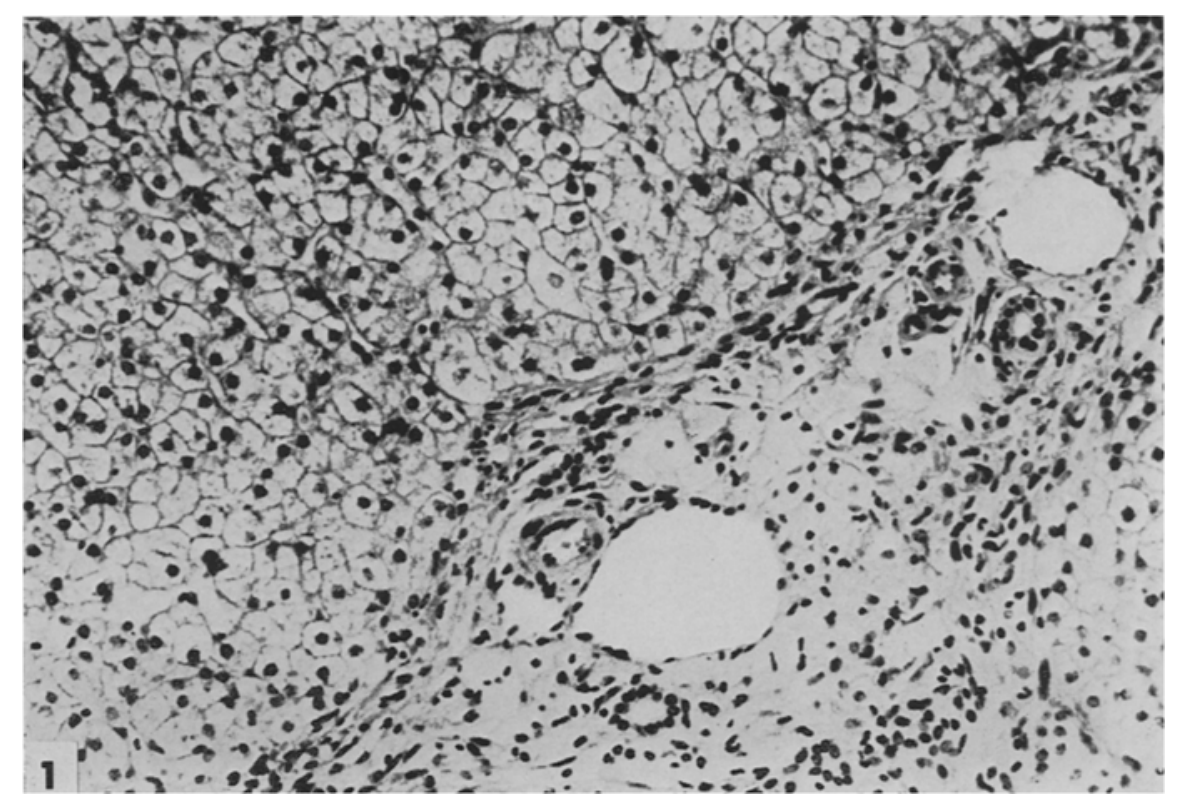

Fig. 1. Both hepatic and Kupffer cells were light and had a ballooned cytoplasm. There were numerous macrophages which had light and swollen cytoplasm in the periportal area. H.E. $\times 100$

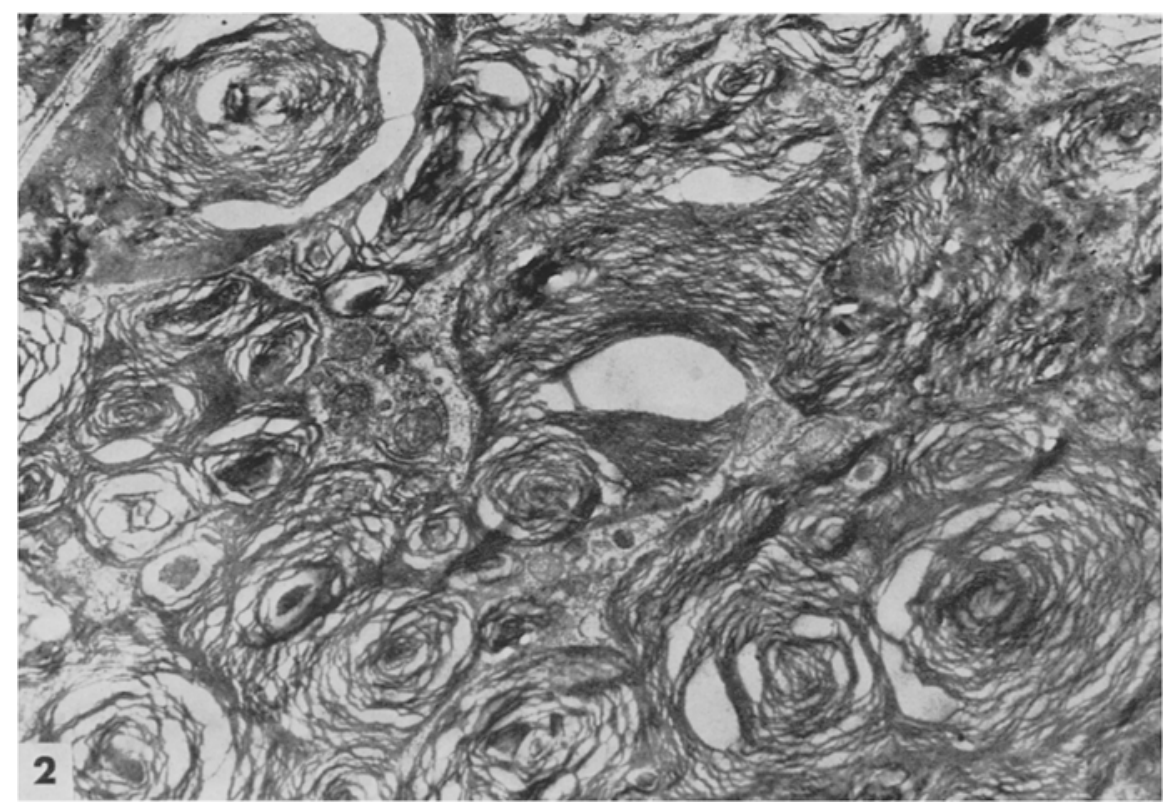

Fig. 2. The reticular cells of lymphnodes were shown to be filled with cytoplasmic inclusion bodies, some of which took the shape of concentric lamellar bodies. $\times 3,500$ 


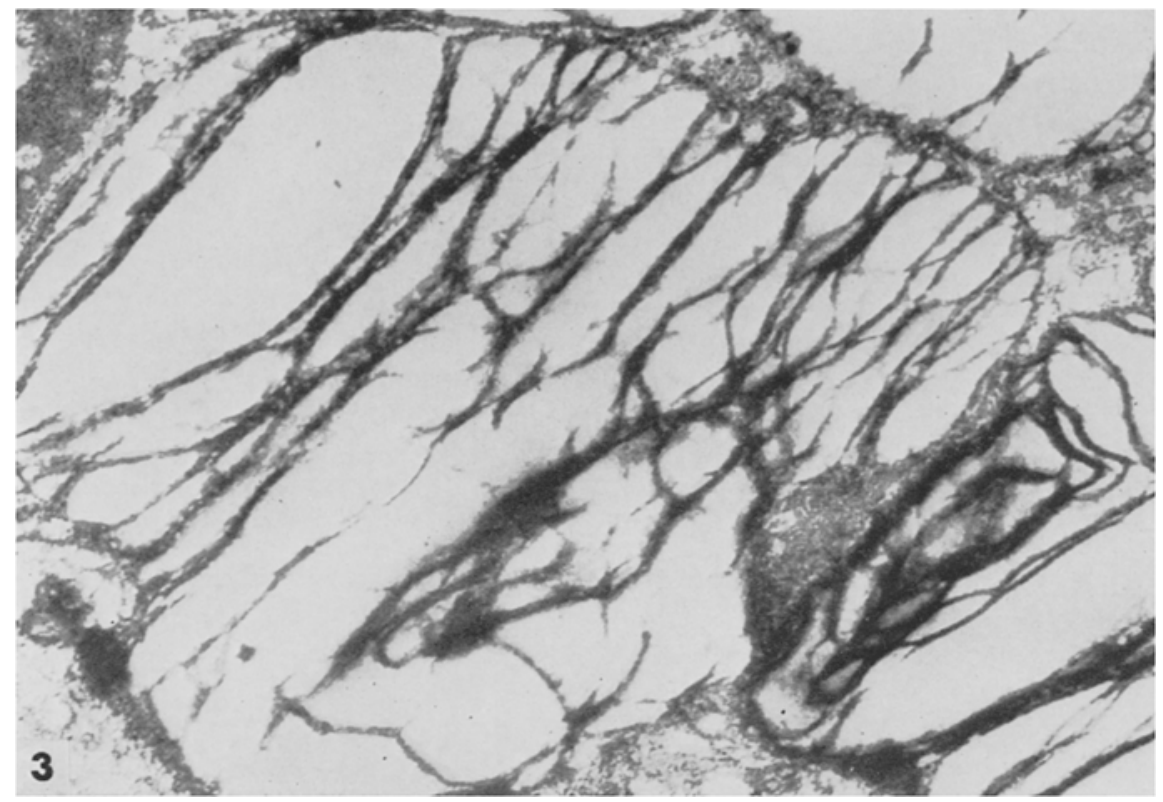

Fig. 3. Cytoplasmic inclusion bodies which appeared like zebra bodies. $\times 7,000$

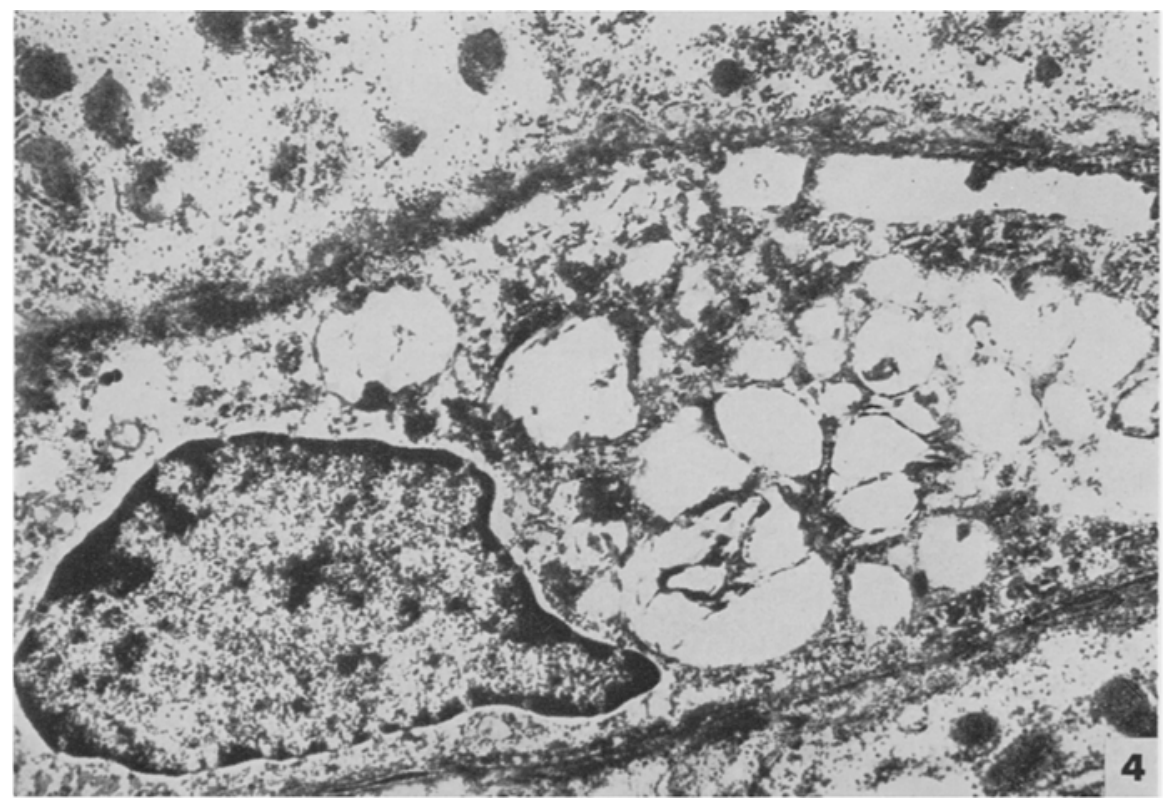

Fig. 4. Cytoplasmic inclusion bodies in the Kupffer cells. $\times 5,000$ 
Table 1. Sphingomyelinase activity in the liver. Enzyme activities are expressed as nmol of sphingomyelin hydrolysed $/ \mathrm{hr} / \mathrm{mg}$ protein.

\begin{tabular}{lr}
\hline & Sphingomyelinase \\
\hline Patient & 0.13 \\
Control 1 & 6.93 \\
2 & 12.96 \\
3 & 9.50 \\
4 & 12.89 \\
5 & 13.09 \\
\hline
\end{tabular}

Table 2. Enzyme activities of the leucocytes.

\begin{tabular}{cccccc}
\hline & $\begin{array}{c}\beta \text {-Galacto- } \\
\text { sidase a }^{2}\end{array}$ & $\begin{array}{c}\beta \text {-Glucuro- } \\
\text { nidase a }\end{array}$ & $\begin{array}{c}\beta \text {-Glucosami- } \\
\text { nidase a }\end{array}$ & $\begin{array}{c}\alpha \text {-Manno- } \\
\text { sidase a }^{\text {a }}\end{array}$ & $\begin{array}{c}\text { Sphingomye- } \\
\text { linase }\end{array}$ \\
\hline Patient & 4.77 & 5.29 & 26.9 & 7.8 & 0.99 \\
Father & 5.56 & 3.68 & - & 4.4 & 10.12 \\
Mother & 3.48 & 3.86 & 23.9 & 5.1 & 4.95 \\
Brother & 3.92 & 3.39 & 24.5 & 3.3 & 16.71 \\
Control 1 & 4.18 & 4.21 & 23.2 & 6.5 & 14.83 \\
2 & 5.65 & 5.26 & 20.2 & 5.7 & 14.68 \\
3 & 4.85 & 6.78 & 30.5 & 7.6 & 28.53 \\
Normal & & & & & \\
m \pm SD & $2.88 \pm 1.06$ & $4.03 \pm 1.34$ & $20.7 \pm 6.1$ & $4.8 \pm 2.1$ & \\
(n) & $(36)$ & $(57)$ & $(23)$ & $(72)$ & \\
\hline
\end{tabular}

a Enzyme activities are expressed as nmol of 4-MU liberated/min/mg protein. b Enzyme activities are expressed as nmol of sphingomyelin hydrolysed $/ \mathrm{hr} / \mathrm{mg}$ protein.

Table 3. Chronic Niemann-Pick disease with sphingomyelinase deficiency in Japan.

\begin{tabular}{lcccc}
\hline & Case 1 & Case 2 & Case 3 & Present case \\
\hline Age & 9 Y5M & $18 \mathrm{Y}$ & 2 Y9M & 3Y8M \\
Sex & Male & Male & Male & Female \\
Mental retardation & $(+)$ & $(+)$ & $(-)$ & $(-)$ \\
Short stature & $(+)$ & $(-)$ & $(+)$ & $(+)$ \\
Hepatosplenomegaly & $(+)$ & $(+)$ & $(+)$ & $(+)$ \\
Chest X-ray abnormality & $(+)$ & $(+)$ & $(+)$ & $(+)$ \\
MCB & $(+)$ & $(+)$ & $(+)$ & $(+)$ \\
Foamy cells & $(+)$ & $(+)$ & $(+)$ & $(+)$ \\
Cherry-red spots & $(-)$ & $(-)$ & $(+)$ & $(-)$ \\
Elevation of triglyceride and $\beta$-lipoprotein & $(-)$ & $(-)$ & $(-)$ & $(+)$ \\
Elevation of S-GOT and S-GPT & $(-)$ & $(-)$ & $(+)$ & $(+)$ \\
Sphingomyelinase activities & N.D. & N.D. & Low & Low \\
of the leucocyte of parents & N.D. & N.D. & Trace & Trace \\
Sphingomyelinase activities & Trace & Trace & Trace & Trace \\
of the leucocyte & Sphingomyelinase activities of the liver & N.)
\end{tabular}

MCB, membranous cytoplasmic bodies; N.D., Not determined. Case 1 and Case 2 were reported by Sogawa, H. et al. $(1976,1978)$, case 3 was reported by Uetani, Y. et al. (1978).

Vol. 26, No. 3, 1981 
chinical and laboratory data of all.

Sogawa et al. (1976) who reported cases 1 and 2 described that mental retardations of these two cases was specific findings. These two patients were later reported as a variant type of Niemann-Pick disease, not as Type B (Sogawa et al., 1978). Case 3 is also atypical because of the presence of macular cherry-red spots. It is impossible to differentiate these four patients in Japan on the bases of sphingomyelinase activities in the liver and leucocytes. The four patients summarized herein raised the question of classification of Niemann-Pick disease, even among Crocker's type $B$; phenotypic variabilities were present in patients with a chronic course with profound sphingomyelinase deficiencies.

Hammersen et al. (1979) recently reported a 4 year old girl with chronic Niemann-Pick disease presenting cherry-red spots and considered the patient as a variant of type B Niemann-Pick disease. The 3 year old girl reported by Koranyi and Rajik (1976) is noteworthy in this context, as in her case there was macular change and mental retardation as well as hepatosplenomegaly, pulmonary changes, foamy cells in bone marrow and sphingomyelin accumulation in the liver, although the sphingomyelinase activity was not determined. It has not been determined whether the patients diagnosed later in adulthood as Niemann-Pick disease Type E might in fact have been a Type B. Whether differences in the clinical findings in these patients are due to only phenotypic variabilities seen with common genetic disturbances or due to genetic heterogeneities remain to be elucidated.

\section{REFERENCES}

Callahan, J.W., Kahlil, M., and Gerrie, J. 1974. Isoenzyme of sphingomyelinase and the genetic defect in Niemann-Pick disease, Type C. Biochem. Biophys. Res. Commun. 58: 384-390.

Crocker, A.C. 1961. The cerebral defect in Tay-Sachs disease and Niemann-Pick disease. J. Neurochem. 7: 69-80.

Fredrickson, D.S., and Sloan, H.R. 1972. Sphingomyelin lipidosis. In: The Metabolic Basis of Inherited Disease. 3rd Ed. McGraw-Hill Book Co., New York. pp. 783-807.

Hammersen, G., Oppermann, H.C., Harms, E., Blassman, K., and Harzer, K. 1979. Oculo-neural involvement in an enzymatically proven case of Niemann-Pick disease Type B. Eur. J. Pediatr. 132: 77-84.

Koranyi, G., and Rajik, A. 1976. Sphingomyelin Lipidose. Mschr. Kinderheilk. 124: 712-716.

Lowry, O.H., Rosebrough, N.J., Farr, A.L. and Randall, R.J. 1951. Protein measurement with the folin phenol reagent. J. Biol. Chem. 193: 265-275.

Niemann, A. 1914. Ein unbekanntes Krankheitsbilt. Jahrb. Kinderheilk. 79: 1-10.

Pick, L. 1927. Über die lipoidzellige Splenohepaiomegalie Typus Niemann-Pick als Stoffwechselerkrankung. Med. Klin. 23: 1483-1488.

Pick, L., and Bielschowsky, M. 1927 . Über lipoidzellige Splenomegalie (Typus Niemann-Pick) und amaurotishe Idiotie. Klin. Wschr. 6: 1631-1632.

Schneider, P.B., and Kennedy, E.P. 1967. Sphingomyelinase in normal human spleens and in spleens from subjects with Niemann-Pick disease. J. Lipid Res. 8: 202-209.

Sloan, H.R., Uhlendorf, B.W., Kanfer, J.N., Brady, R.O., and Fredrickson, D.S. 1969. Deficiency of sphingomyclin-cleaving enzyme activity in tissue cultures derived from patients with Niemann-Pick disease. Biochem. Biophys. Res. Commun. 34: 582-588. 
Sogawa, H., Horino, K., Nakamura, T., Kudoh, T., Yamanouchi, T., Minami, R., Nakao, T., Watanabe A., and Matsuura, Y. 1978. Chronic Niemann-Pick disease with sphingomyelinase deficiency in two brother with mental retardation. Eur. J. Pediatr. 128: 235-240.

Sogawa, H., Watanabe, A., Yamanouchi, T., Nakamura, T., Kudoh, T., Oyanagi, K., Orii, T., and Horino, K. 1976. The brother of Niemann-Pick disease type B. Acta Pediat. Jpn. (in Japanese) 80: 19-26.

Stoffel, W., Lekim, D., and Tschung, T.S. 1971. A simple chemical method for labelling phosphatidylcholine and sphingomyelin in the choline moiety. Hoppe-Seyler's Z. Physiol. Chem. 325: 1058-1064.

Sudo, M., Tanioka, K., and Momoi, T. 1978. Stability of $\alpha$-glucosidase. Ann. Pediatr. Jpn. 24: 86-90.

Uetani, Y., Kimura, A., Miwa, T., Kihara, A., Umesawa, Y., Matsunaga, T., and Yamamoto, M. 1978. A case of Niemann-Pick disease. Acta. Pediatr. Jpn. (in Japanese) 82: 1277-1283. 